\title{
The Effects of Various Types of Press Wheels Mounted on Pneumatic Precise Drilling Machine on the Quality Criteria of Black Carrot
}

\author{
Hüseyin BÜLBÜL ${ }^{1}$, Haydar HACISEFEROĞULLARI *1 \\ ${ }^{1}$ Selcuk University, Department of Agricultural Machineries and Technologies Engineering, Konya, Turkey
}

Received: 28 April 2017 - Accepted: 03 October 2017

\begin{abstract}
Black carrots are consumed as fresh vegetables in Turkey and are preferred in the form of fermented beverages in large quantities. Black carrots are cultivated in different regions of Turkey. The black carrot is cultivated heavily in the Eregli region. In this region, the highest yields for black carrots are obtained by planting on the ridge at narrow interval range with triplet drilling. In this study, the effects of front and rear stainless steel press wheel $\left(\mathrm{BT}_{1}\right)$, front and rear rubber press wheel $\left(\mathrm{BT}_{2}\right)$ and front and rear rubber press wheel and triple narrow intermediate rubber wheels $\left(\mathrm{BT}_{3}\right)$ on black carrot quality criteria in field conditions were investigated. According to results, yield, single carrot mass, diameter and length varied between, 15.11 and $41.61 \mathrm{t} \mathrm{ha}^{-1}, 76.96$ and 226.43 $\mathrm{g}, 33.61$ and $53.14 \mathrm{~mm}$, and 193.65 and $237.33 \mathrm{~mm}$ respectively. It was found that total phenolic varied between 349.80 and $745.37 \mathrm{mg}$ gallic acid equivalent $\left(100 \mathrm{ml}^{-1}\right.$ and the antioxidant activity value, determined by DPPH, varied between $26.71 \%$ and $54.80 \%$.
\end{abstract}

Keywords: Press wheel, plant distribution on the row, yield, black carrot, quality criteria

\section{INTRODUCTION}

The carrot (Daucus carota) is a perennial plant from the Umbelliferae family. In Turkey, carrots are produced to a large extent in the Central Anatolia and Konya regions. Black carrots are an important agricultural product and source of income for Turkey, specifically in the Eregli District. It is estimated 40000 to 50000 decares of production are made in the area and according to the production area by years, approximately 100000 to 150000 tons of products have been manufactured. Although the fresh consumption of black carrots in our country is low, it is nevertheless preferred as a fermented beverage in high quantities.

Considering the production history of black carrots in the region until 2008, exports of black carrots were primarily as a raw material, and since then exports as a concentrate (i.e. as a fermented drink) have gained greater momentum. In production, approximately $80 \%$ is concentrated, while $20 \%$ is used in the turnip industry. The turnip juice obtained from the black carrot is a fermented product with many appealing properties [1]. One of the most important

${ }^{*}$ Corresponding Author E-mail: hhsefer@selcuk.edu.tr

ISSN: 2148-6905 online /(C) 2017

DOI: $10.21448 /$ ijsm. 364185 
properties of turnip juice is the lactic acid content. Aside from the sour taste encountered in turnip juice, lactic acid is known also to be a digestive facilitator, refresher, $\mathrm{pH}$ regulator of the digestive system, and provides other more beneficial properties to the body in order to utilize more minerals [2].

Black carrots are a potential source of anthocyanin pigment with high antioxidant activity. Its composition is characterized by its high anthocyanin content $\left(1750 \mathrm{mg} \mathrm{kg}^{-1}\right)$ and special quality parameters [3]. Anthocyanins are best known as natural food dyes that provide the bright red color in some foods such as blueberries and pomegranates, and moreover are considered an important alternative to synthetic dyes in the dyeing of many foods [4 and 5]. Fruit colored with black carrot juice provides significant benefits against chronic diseases due to the high anthocyanin content. In vascular diseases for instance, particularly arterial thickening, cancer, diabetes and disorders of nerve degeneration and in certain eye diseases, it has been shown to be especially therapeutic [6 and 7]. The pigment of the anthocyanin in black carrots is acylated with p-coumaric, ferulic, p-hydroxybenzoic acid and sinapic acids and thus more resistance to hydration, light and food $\mathrm{pH}$. The black carrot extract gives an excellent strawberry red brilliance at acidic $\mathrm{pH}$ values. Fruit juice is used for coloring, softness, protection, glazing, and in pastries; as such, an e-number is not required in food labels because it is a natural additive [8]. Black carrot concentrate is also used as natural fabric dye. Synthetic fabric dyes is expected to be prohibited in the coming years and thus the use of natural dyes such as that from black carrots will be more important.

In recent years, narrow row spacing vacuum pneumatic precision sowing machines have begun to be used in the region. The pressure wheels used in these machines are flat sheet or flat tire. These machines also have pressure wheels with triple narrow tires in the middle. By planting two or three rows of carrots instead of a single row of seeds, agricultural products with high quality market value can be obtained. It has been reported that the seed quality can increase due to the uniformity of the habitat area within the narrow row spacing [9]. For this reason, it was aimed to determine the effects of press wheels on plant distribution uniformity, yield, and carrot quality in black carrot cultivation with a pneumatic sensitive vegetable sowing machine.

\section{MATERIAL and METHODS}

The research was carried out in the village of Kuzukuyusu, located in the Eregli District of Turkey, and according to the trial design of the divided parcels, three repetitions were conducted. In the experiments, a local ancient carrot genotype known with its common name "Eregli variety" (Daucus carota L.) was used. The seeds were uncoated, with a thousand seed weight of about $1.65 \mathrm{~g}$ and $88 \%$ germination rate as determined in the laboratory.

The sowing was done in three rows in the back and $7.5 \mathrm{~cm}$ between rows (Figure 1). In the experiments, the seeds were made at the same planting depth in all applications. The schematic view of the pneumatic precision vegetable seeding machine is given in Figure 2 . The feed rate of the sowing machine was chosen to be $0.75 \mathrm{~m} \mathrm{~s}^{-1}$.

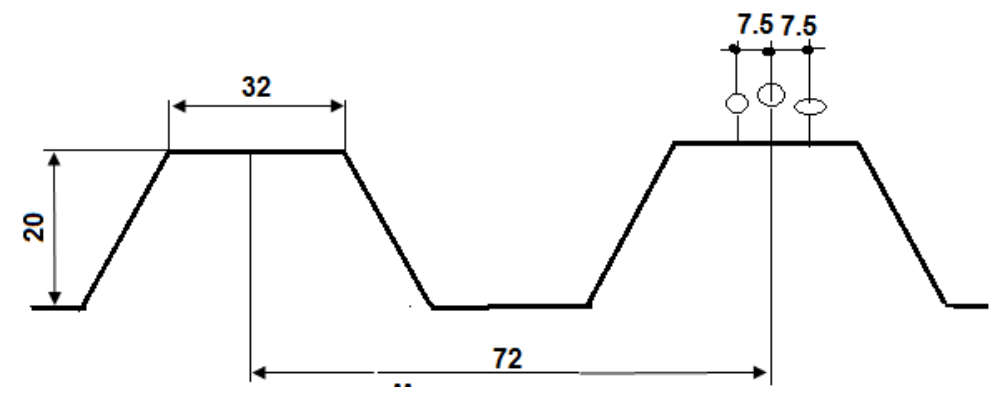

Figure 1. Measurements of the back ridge (Measurements $\mathrm{cm}$ ) 


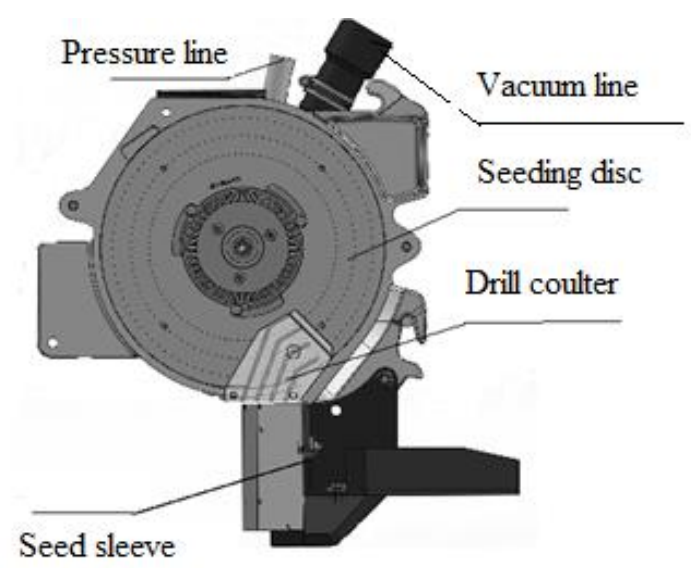

Figure 2. Schematic view of the sowing unit

The research was conducted on three different rows with varying sowing distances $\left(Z_{1}=2.38, Z_{2}=4.65\right.$ and $\left.Z_{3}=6.78 \mathrm{~cm}\right)$ and on three different rollers. These pressure wheels consisted of a front and rear pressure tire $\left(\mathrm{BT}_{1}\right)$, a front and rear pressure sheet $\left(\mathrm{BT}_{2}\right)$, and a front and rear pressure tire with a triple narrow tire $\left(\mathrm{BT}_{3}\right)$ in the middle (i.e. Figures 3,4 and 5, respectively). Each parcel is arranged to have a length of $50 \mathrm{~m}$ and a width of $2.8 \mathrm{~m}$.

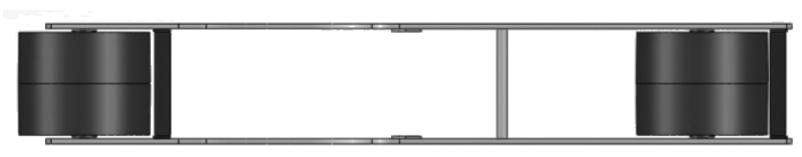

Figure 3. Front and rear pressure tire $\left(\mathrm{BT}_{1}\right)$

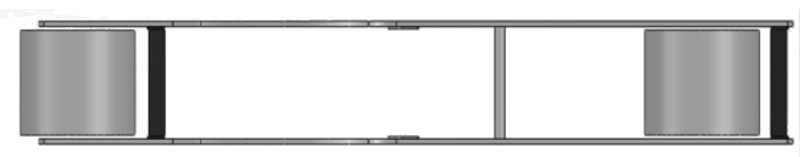

Figure 4. Front and rear pressure sheet $\left(\mathrm{BT}_{2}\right)$

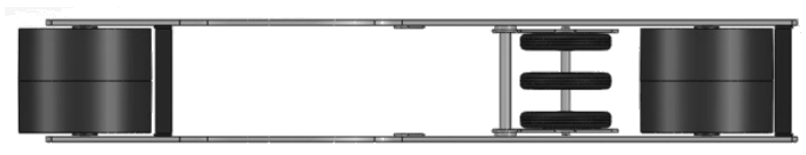

$\begin{array}{ll}\text { Material } & : \text { Tire } \\ \text { Diameter } & : 250 \mathrm{~mm} \\ \text { Width } & : 200 \mathrm{~mm} \\ \text { Mass } & : 72.9 \mathrm{~N}\end{array}$

$\begin{array}{ll}\text { Material } & : \text { Sheet } \\ \text { Diameter } & : 217 \mathrm{~mm} \\ \text { Width } & : 200 \mathrm{~mm} \\ \text { Mass } & : 59.7 \mathrm{~N}\end{array}$

$\begin{array}{lll}\text { Narrow wheel } & \\ \text { Material } & & : \text { Tire } \\ \text { Diameter } & & : 180 \mathrm{~mm} \\ \text { Width } & & : 30 \mathrm{~mm} \\ \text { Mass } & : 10.6 \mathrm{~N} \\ \text { Number } & & : 3 \text { pieces }\end{array}$

Figure 5. Front and rear pressurized tire and pressure spring adjustable medium triple narrow tire $\left(\mathrm{BT}_{3}\right)$

The clay content in the experimental field was determined to be $22.90 \%$, with a silt content of $7.50 \%$, and a sand content $69.90 \%$. The soil texture class was categorized as Sandyclay-loamy. Soils had a low organic matter content $(1.45 \%)$ and aggregate stability value $(5.90 \%)$. The soil was considered to be a very high calcareous soil, with lime content as $37.49 \%$ $\mathrm{CaCO}_{3}$ and a $\mathrm{pH}$ value of 8.27 , denoting a middle grade alkaline class.

Sowing was carried out from the end of April to mid-November 2015. Meteorological data from April to November covering these vegetation periods are given in Table 1. The seed bed was prepared in mid-February and plowed at the end of March 2015. Using a centrifugal distributor, a DAP fertilizer rate of $40 \mathrm{~kg} \mathrm{da}^{-1}$ was distributed in late April 2015. The seed bed 
was prepared by using horizontal rototill in late April and sowing ridges were formed with a ridge making machine (Table 2). The harvesting was carried out in mid-November 2015 and the experimental parcels were irrigation was supplied 23 times to, with $1904 \mathrm{~mm}$ water given in total.

Table 1. Monthly meteorological data from the black carrot growing season [10].

\begin{tabular}{lcccc}
\hline $\begin{array}{l}\text { Months } \\
(2015)\end{array}$ & $\begin{array}{r}\text { Average Monthly } \\
\text { Maximum Temperature } \\
\left({ }^{\circ} \mathrm{C}\right)\end{array}$ & $\begin{array}{c}\text { Average Monthly } \\
\text { Minimum Temperature } \\
\left({ }^{\circ} \mathrm{C}\right)\end{array}$ & $\begin{array}{c}\text { Monthly Average } \\
\text { Temperature } \\
\left({ }^{\circ} \mathrm{C}\right)\end{array}$ & $\begin{array}{c}\text { Monthly Average } \\
\text { Rainfall } \\
(\mathrm{mm})\end{array}$ \\
\hline April & 16.0 & 3.1 & 11.3 & 32.4 \\
May & 24.0 & 9.3 & 17.8 & 45.0 \\
June & 26.3 & 12.6 & 19.9 & 73.8 \\
July & 31.8 & 15.0 & 26.6 & 0.2 \\
August & 32.6 & 17.0 & 27.3 & 9.6 \\
September & 31.4 & 13.6 & 24.3 & 0.0 \\
October & 21.9 & 9.4 & 16.7 & 49.2 \\
November & 15.6 & 1.0 & 8.6 & 0.0 \\
\hline
\end{tabular}

Table 2. Agricultural operations applied to the experimental plots in 2015 production

\begin{tabular}{ll}
\hline Dates & Agricultural practices \\
\hline 16.02.2015 & Seed bed preparation \\
30.03.2015 & Plowing \\
23.04.2015 & Centrifugal fertilizer distribution (DAP with $40 \mathrm{~kg} \mathrm{da}^{-1}$ fertilizer norm) \\
25.04.2015 & Preparation of seed bed with horizontal rototil \\
26.04 .2015 & Sowing preparation of ridges \\
26.04.2015 & Sowing operation \\
21.05 .2015 & Inter-row hoeing \\
28.05 .2015 & Weed treatment (Linourin $\left.150 \mathrm{~g} \mathrm{da}^{-1}\right)$ \\
04.06.2015 & Sprinkler irrigation with $15 \mathrm{~kg} \mathrm{da}^{-1} \mathrm{fertilizer} \mathrm{UREA}_{17.06 .2015}$ Fertile intermediate diameter $\left(15 \mathrm{~kg} \mathrm{da}^{-1}\right.$ fertilizer UREA) \\
24.06 .2015 & Addition of humic acid with sprinkler irrigation $2 \mathrm{~kg} \mathrm{da}^{-1}$ \\
29.06 .2015 & Removal of weeds \\
05.07.2015 & Ammonium nitrate fertilizer application at $10 \mathrm{~kg} \mathrm{da}^{-1}$ with sprinkler irrigation \\
14.07.2015 & Ammonium nitrate fertilizer application at $10 \mathrm{~kg} \mathrm{da}^{-1}$ with sprinkler irrigation \\
22.07 .2015 & Ammonium nitrate fertilizer application at $10 \mathrm{~kg} \mathrm{da}^{-1}$ with sprinkler irrigation \\
25.07 .2015 & Inter-row hoeing \\
08.08 .2015 & Remove bolting plants \\
16.09 .2015 & Remove bolting plants \\
18.11 .2015 & Harvesting \\
\hline
\end{tabular}

Spacing measurements on row were performed on a $10 \mathrm{~m}$ length of row on randomly selected three rows of each plot 30 days after the seeding date and plant spacing was measured with a steel rule. Variation coefficient for on-row plant distribution was calculated by using the following equation.

$$
\begin{aligned}
\mathrm{VC}= & \sqrt{\frac{\sum(\mathrm{x}-\overline{\mathrm{x}})^{2}}{\mathrm{n}-1} \cdot \frac{100}{\mathrm{x}}} \\
\mathrm{x} & : \text { Average planting spacing on-row }(\mathrm{cm}) \\
\overline{\mathrm{x}} & : \text { Measured planting spacing on-row }(\mathrm{cm}) \\
\mathrm{n} & : \text { Number of measured planting spacing on-row } \\
\mathrm{VC} & : \text { Variation coefficient }(\%)
\end{aligned}
$$


In yield measurements, five carrot samples of approximately $1.4 \mathrm{~m}$ in length were removed, cleaned and weighed from each plot. Black carrots were evaluated according to the extra class, based on the carrot boiling standard specified in TS 1193. Larger diameters of extruded carrots should be between 25 and $45 \mathrm{~mm}$ in diameter and masses between 50 and 200 $\mathrm{g}$ [11]. The method recommended by [12] for the determination of total phenolic materials of the samples taken from the field was used. This method is based on the fact that the phenolic compounds form a blue complex by reducing the phosphololybdic-phosphotungstic solution of the Folin-Ciocalteu solution and that this blue color is measured colorimetrically [13]. The results are given as Gallic acid equivalent (GAE). Antioxidant activity was determined by the DPPH (1,1-diphenyl-2-picrylhydrazyl) method [14].

It was analyzed by the Shapiro-Wilk test to determine whether the data showed a normal distribution. Variance analysis was performed using the MINITAB 16 program. LSD analysis was performed on the properties with variance at $1 \%$ and at least $5 \%$ significance level among the applications. These analyzes and calculations were made in the MSTAT-C package software.

\section{RESULTS}

Plant distribution uniformity and yield values for the 2015 black carrot growing season are given in Table 3. As it is shown in the table, under field conditions, the average rate of increase of plant per distance over the designated row was obtained. The lowest average was determined for the $\mathrm{BT}_{2}$ press at 2.86 while the highest at 3.42 was obtained in the $\mathrm{BT}_{1}$ press wheel. When the coefficient of variation was evaluated, the average coefficient of variation obtained at three distances was $\mathrm{BT}_{1}$ with $97.85 \%, \mathrm{BT}_{2}$ with $87.07 \%$ and $\mathrm{BT}_{2}$ with $86.88 \%$. Yield values changed between $15.11 \mathrm{t} \mathrm{ha}^{-1}$ and $46.82 \mathrm{t} \mathrm{ha}^{-1}$. The maximum yield value was shown to be with the $\mathrm{BT}_{2}$ pressure wheel with an average of $30.70 \mathrm{t} \mathrm{ha}^{-1}$, followed by the $\mathrm{BT}_{3}$ pressure wheel (i.e. $30.62 \mathrm{t} \mathrm{ha}^{-1}$ ) and the $\mathrm{BT}_{1}$ pressure wheel with $30.07 \mathrm{t} \mathrm{ha}^{-1}$. A variance analysis on yield values, indicated there was no statistically significant relationship between pressure wheels $(\mathrm{F}=0.30)$. When the distance $(\mathrm{F}=11.82)$ was examined, the yield value of $36.33_{\mathrm{a}} \mathrm{t} \mathrm{ha}^{-1}$ was obtained at the $\mathrm{Z}_{1}$ planting distance, 30.14ab $\mathrm{t} \mathrm{ha} \mathrm{a}^{-1}$ at the planting distance $\mathrm{Z}_{2}$ and $22.91_{\mathrm{c}} \mathrm{t} \mathrm{ha}^{-1}$ at the planting distance $\mathrm{Z}_{3}$. Differences between the positions above and below were statistically significant at $1 \%$ level $(\mathrm{LSD}=7.985)$, but no difference can be drawn between the $\mathrm{Z}_{1}$ and $\mathrm{Z}_{2}$ planting distances.

However, a significant interaction was found between pressure wheel and row distance $(\mathrm{F}=3.78)$ and the highest yield values were obtained at the $\mathrm{Z}_{1}$ sowing of the pressure wheels. The average yield of agricultural enterprises in the region varies between 2 and $5 \mathrm{t} \mathrm{da}^{-1}$. When an evaluation is made in this respect, it can be said that the regional average yields are achieved outside the $\mathrm{Z}_{3}$ planting distance.

The mass, diameter and height values obtained after measurement of the black carrots taken from the parcels are given in Table 4. As a result of the analysis of variance applied to the mass, diameter and height values of black carrots, the pressure wheel was not found statistically significant, but the distance between row spacing and interaction pressure wheel by the distance between the row spacing was statistically significant. When the mass values of black carrots were examined, results showed there was a change between $76.96 \mathrm{~g}$ and 226.43 g. When the above distances were examined, it was found that the highest mass value was obtained at a distance of $\mathrm{Z}_{3}$ with $178.97 \mathrm{~g}$ (Table 5). However, when the interaction was examined, the highest mass value $(226.43 \mathrm{~g})$ was obtained in the parameter of $\mathrm{BT}_{3} \mathrm{Z}_{3}$. 
Table 3. Plant distribution smoothness and yield values on row in black carrot cultivation

\begin{tabular}{lcccc}
\hline $\begin{array}{l}\text { Pressure } \\
\text { Wheel }\end{array}$ & $\begin{array}{c}\text { Row over } \\
\text { theoretical distance } \\
(\mathrm{cm})\end{array}$ & $\begin{array}{c}\text { Average Row } \\
\text { Spacing } \\
(\mathrm{cm})\end{array}$ & $\begin{array}{c}\text { The coefficient } \\
\text { of variation } \\
(\%)\end{array}$ & $\begin{array}{c}\text { Yield } \\
\left(\mathrm{t} \mathrm{ha}{ }^{-1}\right)\end{array}$ \\
\hline \multirow{3}{*}{$\mathrm{BT}_{1}$} & 2.38 & 11.44 & 113.25 & $41.61_{\mathrm{a}}$ \\
& 4.65 & 14.35 & 102.03 & $33.48_{\mathrm{abc}}$ \\
\hline \multirow{3}{*}{$\mathrm{BT}_{2}$} & 6.78 & 16.05 & 78.28 & $15.11_{\mathrm{d}}$ \\
& 2.38 & 8.67 & 84.36 & $31.95_{\mathrm{abc}}$ \\
& 4.65 & 12.49 & 91.25 & $30.61_{\mathrm{bc}}$ \\
$\mathrm{BT}_{3}$ & 6.78 & 15.24 & 85.59 & $29.56_{\mathrm{bc}}$ \\
& 2.38 & 7.58 & 86.40 & $35.44_{\mathrm{ab}}$ \\
& 4.65 & 13.56 & 91.08 & $26.34_{\mathrm{bc}}$ \\
\hline
\end{tabular}

Table 4. Mass, diameter and height values of black carrots and applied LSD test

\begin{tabular}{|c|c|c|c|c|}
\hline $\begin{array}{c}\text { Pressure } \\
\text { Wheel }\end{array}$ & $\begin{array}{l}\text { Distance over } \\
\text { the row }\end{array}$ & $\begin{array}{l}\text { Mass } \\
(\mathrm{g})\end{array}$ & $\begin{array}{l}\text { Diameter } \\
(\mathrm{mm})\end{array}$ & $\begin{array}{l}\text { Height } \\
(\mathrm{mm})\end{array}$ \\
\hline \multirow{3}{*}{$\mathrm{BT}_{1}$} & $\mathrm{Z}_{1}$ & $76.96_{d}$ & $33.61_{c}$ & $208.63_{\mathrm{bcd}}$ \\
\hline & $\mathrm{Z}_{2}$ & $142.59_{\mathrm{b}}$ & $41.05_{b}$ & $209.25_{\mathrm{bcd}}$ \\
\hline & $\mathrm{Z}_{3}$ & $152.60_{\mathrm{b}}$ & $43.40_{\mathrm{b}}$ & $213.82_{\mathrm{bc}}$ \\
\hline \multirow{3}{*}{$\mathrm{BT}_{2}$} & $\mathrm{Z}_{1}$ & $83.39_{\mathrm{d}}$ & $35.30_{\mathrm{c}}$ & $193.65_{d}$ \\
\hline & $\mathrm{Z}_{2}$ & $134.98_{\mathrm{bc}}$ & $42.79_{b}$ & $216.63_{\mathrm{bc}}$ \\
\hline & $\mathrm{Z}_{3}$ & $157.88_{\mathrm{b}}$ & $44.63_{\mathrm{b}}$ & $224.45_{\mathrm{ab}}$ \\
\hline \multirow{4}{*}{$\mathrm{BT}_{3}$} & $\mathrm{Z}_{1}$ & $81.11_{\mathrm{d}}$ & $33.74_{c}$ & $201.85_{\mathrm{cd}}$ \\
\hline & $\mathrm{Z}_{2}$ & $99.47_{\mathrm{cd}}$ & $41.33_{\mathrm{b}}$ & $216.03_{b c}$ \\
\hline & $\mathrm{Z}_{3}$ & $226.43_{\mathrm{a}}$ & $53.14_{\mathrm{a}}$ & $237.33_{\mathrm{a}}$ \\
\hline & & $\operatorname{LSD}(p<0.01)=1.851$ & $\operatorname{LSD}(p<0.05)=5.598$ & LSD $(p<0.05)=10.030$ \\
\hline
\end{tabular}

Table 5. LSD test applied to the mass, diameter and height values obtained from averages over distance

\begin{tabular}{cccc}
\hline $\begin{array}{c}\text { Distance } \\
\text { over Row }\end{array}$ & $\begin{array}{c}\text { Average Mass } \\
(\mathrm{g})\end{array}$ & $\begin{array}{c}\text { Average Diameter } \\
(\mathrm{mm})\end{array}$ & $\begin{array}{c}\text { Average Height } \\
(\mathrm{mm})\end{array}$ \\
\hline $\mathrm{Z}_{1}$ & $80.49_{\mathrm{c}}$ & $34.21_{\mathrm{c}}$ & $201.38_{\mathrm{c}}$ \\
$\mathrm{Z}_{2}$ & $125.68_{\mathrm{b}}$ & $41.72_{\mathrm{b}}$ & $213.97_{\mathrm{b}}$ \\
$\mathrm{Z}_{3}$ & $178.97_{\mathrm{a}}$ & $47.06_{\mathrm{b}}$ & $225.20_{\mathrm{a}}$ \\
\hline & $\mathrm{LSD}(\mathrm{p}<0.01)=1.068$ & $\mathrm{LSD}(\mathrm{p}<0.01)=4.428$ & $\mathrm{LSD}(\mathrm{p}<0.01)=10.03$ \\
\hline
\end{tabular}

When the diameter measurement values of black carrots were examined, it showed there was a change between $33.61 \mathrm{~mm}$ and $53.14 \mathrm{~mm}$. When the sowing distances were examined, results showed that the highest mass value was obtained at $Z_{3}(47.06 \mathrm{~mm})$ and at $Z_{2}$ planting distance $(41.72 \mathrm{~mm})$ and there was no statistical difference between them. When the spacing interaction with the pressure wheel was examined, the highest diameter value was found for $\mathrm{BT}_{3} \mathrm{Z}_{3}(53.14 \mathrm{~mm})$.

The height values of black carrots varied between $193.65 \mathrm{~mm}$ and $237.33 \mathrm{~mm}$. Results showed that at the planting distance $\mathrm{Z}_{3}$ the highest height average of $225.20 \mathrm{~mm}$ was obtained, however when the distance between the pressure wheel and the row is measured, results showed that $\mathrm{BT}_{2} \mathrm{Z}_{3}(224.45 \mathrm{~mm})$ and $\mathrm{BT}_{3} \mathrm{Z}_{3}(237.33 \mathrm{~mm})$ had the highest values. In a study about yellow carrots it was reported that the maximum length value for Nantura F1 was $18.00 \mathrm{~cm}$ and 17.74 
$\mathrm{cm}$ for Bertan F1 in mid-October of 1999. Furthermore, for the Asubeni F1 variety the highest mass average was $117.7 \mathrm{~g}$ and the lowest length value was 13.72 [15]. In this respect, our values correspond with those of the literature.

Carrots with large diameters entering the extra classifications, and classified according to the carrot boiling standard determined in TS 1193 (i.e. one of the quality criteria of black carrot), must have a diameter ranging between 25-45 mm and a mass value between 50-200 g. Hence, large diameter and mass interval values for our black carrot samples were set according to these standards, and the percentage ratios of the small and large ones from the limit value are given in Table 6.

Table 6. Distribution of diameter and mass values

\begin{tabular}{cccccccc}
\hline \multirow{2}{*}{$\begin{array}{c}\text { Pressure } \\
\text { Wheel }\end{array}$} & Row Spacing & \multicolumn{3}{c}{ Carrot diameter distribution (\%) } & \multicolumn{3}{c}{ Carrot weight distribution (\%) } \\
& & $<24.99$ & $25-45$ & $>45.01$ & $<49.99$ & $50-200$ & $>200.01$ \\
\hline \multirow{2}{*}{$\mathrm{BT}_{1}$} & $\mathrm{Z}_{1}$ & 24.42 & 61.30 & 14.29 & 37.28 & 59.25 & 3.47 \\
& $\mathrm{Z}_{2}$ & 6.67 & 45.48 & 47.85 & 16.23 & 56.68 & 27.09 \\
& $\mathrm{Z}_{3}$ & 0.00 & 24.81 & 75.19 & 1.75 & 42.60 & 55.64 \\
\hline \multirow{3}{*}{$\mathrm{BT}_{2}$} & $\mathrm{Z}_{1}$ & 26.16 & 56.46 & 17.38 & 39.14 & 52.15 & 8.52 \\
& $\mathrm{Z}_{2}$ & 7.88 & 47.02 & 45.10 & 15.93 & 54.36 & 29.71 \\
& $\mathrm{Z}_{3}$ & 14.94 & 45.54 & 39.52 & 20.98 & 56.70 & 22.32 \\
\hline \multirow{2}{*}{$\mathrm{BT}_{3}$} & $\mathrm{Z}_{1}$ & 13.89 & 70.54 & 15.58 & 36.37 & 59.17 & 4.46 \\
& $\mathrm{Z}_{2}$ & 5.50 & 52.97 & 41.53 & 13.33 & 65.75 & 20.92 \\
& $\mathrm{Z}_{3}$ & 7.65 & 51.54 & 41.82 & 20.66 & 56.04 & 23.30 \\
\hline
\end{tabular}

When the distribution of carrot diameters was examined in terms of pressure wheels, it was determined that the distribution between $25-45 \mathrm{~mm}$ diameters varied between $24.81 \%$ and $70.54 \%$ and the distribution of diameters $<24.99 \mathrm{~mm}$ varied between 0 and $26.16 \%$. The distribution of carrot diameters $>45.01$ changed between $14.29 \%$ and $75.19 \%$. Variance analysis for the diameter range $25-45 \mathrm{~mm}$ showed a statistical significance for the parameters of pressure wheel $(\mathrm{F}=6.75)$ and row distance $(\mathrm{F}=16.00)$. When the pressure-only averages were examined, it is clear that in the $\mathrm{BT}_{2}$ and $\mathrm{BT}_{3}$ press wheel, when considering the distances between the rows, the maximum values of the distances between $25-45 \mathrm{~mm}$ were obtained at the $\mathrm{Z}_{1}$ sowing distance (Table 7).

Table 7. LSD test applied to average of $25-45 \mathrm{~mm}$ diameter ranges

\begin{tabular}{cc}
\hline Pressure Wheel Average & Average Row Spacing \\
\hline $\mathrm{BT}_{1} 43.86_{\mathrm{b}}$ & $\mathrm{Z}_{1} 62.76_{\mathrm{a}}$ \\
$\mathrm{BT}_{2} 49.67_{\mathrm{ab}}$ & $\mathrm{Z}_{2} 48.49_{\mathrm{b}}$ \\
$\mathrm{BT}_{3} 58.34_{\mathrm{a}}$ & $\mathrm{Z}_{3} 40.63_{\mathrm{b}}$ \\
\hline $\mathrm{LSD}(\mathrm{p}<0.01)=11.42$ & $\mathrm{LSD}(\mathrm{p}<0.01)=11.42$ \\
\hline
\end{tabular}

Results of measurements of mass values in the study, found the change of rates of carrot fractions with masses of 50-200 g were between $52.84 \%$ and $60.32 \%$. It was determined that the mass of carrots lighter than $49.99 \mathrm{~g}$ is between $18.42 \%$ and $25.35 \%$ and the mass of carrots weightier than $200 \mathrm{~g}$ is between $16.22 \%$ and $28.73 \%$. Analysis of variance applied to carrot fractions with masses between 50 and $200 \mathrm{~g}$ did not reveal a statistically significant relationship between pressure wheel $(\mathrm{F}=1.30)$, row distance $(\mathrm{F}=1.13)$ and pressure wheel and row spacing interactions $(\mathrm{F}=0.96)$.

It can be said that the carrot diameter and mass values were generally evaluated, but the distance of the row had a significant impact. It is evident that the proportion of carrots with diameters $<24.99 \mathrm{~mm}$ and between $25-45 \mathrm{~mm}$ in diameter decreases while the ratio of those 
with diameters $>45.01 \mathrm{~mm}$ increases. In general, it can be said that similar relations are also seen in the diameter range values of $25-45 \mathrm{~mm}$.

The moisture, brix, total phenolic material and antioxidant activity values of the harvested black carrots are given in Table 8 . The obtained moisture values ranged from $83.54 \%$ to $88.11 \%$ and the brixs values ranged from $9.87 \%$ to $11.57 \%$. Total phenolic values of black carrots ranged from 349.80 to $745.37 \mathrm{mg} \mathrm{GAE}(100 \mathrm{ml})^{-1}$. The highest total amount of phenolic material was obtained in the $\mathrm{BT}_{2}$ press wheel [505.68 $\mathrm{mg}$ GAE $(100 \mathrm{ml})^{-1}$ ] and $\mathrm{Z}_{2}$ planting distance $\left[619 \mathrm{mg} \mathrm{GAE}(100 \mathrm{ml})^{-1}\right.$ ] based on the distance averages over the printing press averages. Antioxidant activity values ranged from $28.71 \%$ to $69.48 \%$. The highest antioxidant activity values were found in the $\mathrm{BT}_{2}$ press wheel $(45.50 \%)$ and at the $\mathrm{Z}_{2}$ planting distance $(55.66 \%)$ when the average of the pressurized and row spacing were examined. In studies using black carrots, the antioxidant effect value of the black carrot concentrate was found to be $10.98 \%$ in unpasteurized black carrot juice [16], 187.8 in the amount of phenolic substance in the Antonina variety and $49289 \mathrm{mg} \mathrm{GAE}(100 \mathrm{~g})^{-1}$ in the Purple Haze variety [17]. Reports also stated that the antioxidant effect of black carrot concentrate was $89.71 \%$ [18]. The reported high antioxidant value may be due to the different antioxidant contents of black carrot varieties. The results obtained generally correspond to the data obtained in the investigations.

Table 8. Phenolic substance and antioxidant activity values

\begin{tabular}{ccrccc}
\hline Pressure Wheel & Row Spacing & $\begin{array}{c}\text { Moisture } \\
(\%)\end{array}$ & $\begin{array}{c}\text { Brixs } \\
(\%)\end{array}$ & $\begin{array}{c}\text { Total Phenolic Matter } \\
{\left[\mathrm{mg} \mathrm{GAE}(100 \mathrm{ml})^{-1}\right]}\end{array}$ & $\begin{array}{c}\text { Antioxidant Activity } \\
(\%) \text { DPPH }\end{array}$ \\
\hline \multirow{3}{*}{$\mathrm{BT}_{1}$} & $\mathrm{Z}_{1}$ & 85.22 & 11.57 & 388.43 & 28.71 \\
& $\mathrm{Z}_{2}$ & 83.54 & 11.27 & 745.37 & 54.80 \\
& $\mathrm{Z}_{3}$ & 88.11 & 10.33 & 349.80 & 30.01 \\
\hline \multirow{3}{*}{$\mathrm{BT}_{2}$} & $\mathrm{Z}_{1}$ & 83.63 & 10.37 & 510.47 & 40.30 \\
& $\mathrm{Z}_{2}$ & 85.18 & 9.87 & 633.30 & 69.48 \\
& $\mathrm{Z}_{3}$ & 85.03 & 10.67 & 373.26 & 26.71 \\
\hline \multirow{3}{*}{$\mathrm{BT}_{3}$} & $\mathrm{Z}_{1}$ & 83.61 & 11.37 & 507.01 & 41.81 \\
& $\mathrm{Z}_{2}$ & 85.91 & 11.00 & 478.00 & 42.70 \\
\hline
\end{tabular}

\section{DISCUSSION}

Black carrot farming in the Eregli Region uses seeds that are of a local population. In addition, these seeds are not classified according to quality class. Therefore, the planting quality is deteriorating. According to the results of the experiment, planting should be done on small rows at planting distances in order to obtain the desired plant density in the sowing of black carrots. Field tests suggested to plant with pressure wheels $\left(\mathrm{BT}_{2}\right)$, which are front and rear press wheels, due to the lowest increase in the row, the lowest variation coefficient value and the highest average yield values. In terms of quality criteria, total phenolic substance and antioxidant activity values containing mass values between 50 and $200 \mathrm{~g}$, determined $\mathrm{Z}_{2}$ should be planted at the planting site.

\section{Acknowledgement}

This research covers a part of the first year data of the 1150111 project supported by TUBITAK. Thanks to TÜBITAK-TOVAG group for their contributions. This research is the part of doctoral thesis of Hüseyin BÜLBÜL

\section{Conflict of Interests}

Authors declare that there is no conflict of interests. 


\section{REFERENCES}

[1] Canbaş, A., \& Deryaoğlu, A., (1993). Şalgam Suyunun Üretim Tekniği ve Bileşimi Üzerinde Bir Araştırma. Doğa, 17, 119-129.

[2] Miisoğlu, D., (2004). Effect of enzyme application on the yield and quality during 'şalgam suyu' beverage production. Harran University Graduate School of Natural Sciences Department of Food Engineering, MS Thesis, Şanliurfa (in Turkish).

[3] Kirca, A., Ozkan, M., \& Cemeroglu, B., (2006). Stability of black carrot anthocyanins in various fruit juices and nectars. Food Chemistry, 97(4), 598-605.

[4] Bridle, P., \& Timberlake, C.F., (1997). Anthocyanins as natural food colours-selected aspects. Food Chemistry, 58, 103-109.

[5] Giusti, M.M., \& Wrolstad, R.E., (2003). Acylated anthocyanins from edible sources and their applications in food systems. Biochemical Engineering Journal, 14, 217- 225.

[6] Kong, J.M., Chia, L.S., Goh, N.K., Chia, T.F., \& Brouillard, R., (2003). Analysis and biological activities of anthocyanins. Phytochemistry, 64, 923- 933.

[7] Wrolstad, R.E. (2004). Anthocyanin pigments-Bioactivity and coloring properties. Journal of Food Science, 69(5), 423-428.

[8] Khandare, V., Walia, S., Singh, M., \& Kaur, C., (2011). Black carrot (Daucus carota ssp. sativus) juice: processing effects on antioxidant composition and color. Food and Bioproducts Processing, 89(4), 482-486.

[9] Önal, İ., (2011). Ekim, Bakım ve Gübreleme Makinaları. Ege Üniversitesi Ziraat Fakültesi Yayınları, No: 490, İzmir.

[10] Turkish State Meteorological Service (2015). Meteorological data for Eregli.

[11] TSE, (2007). Havuç Türk Standartları. TS 1193/Aralık 2007, TSE, Ankara.

[12] Abdulkasim, P., Songchitsomboon, S., Techagumpuch, M., Balee, N., Swatsitang, P., \& Sungpuag, N. (2007). Antioxidant capacity, total phenolics and sugar content of selected Thai health beverages. International Journal of Food Sciences and Nutrition, 58(1), 77-85.

[13] Ozdemir, A.N. (2001). Researches on the Production of Pomegranate Juices. Hacettepe University Graduate School of Natural Sciences Department of Food Engineering, PhD Thesis, Ankara (in Turkish).

[14] Brand-Williams, W., Cuvelier, M.E., \& Berset, C., (1995). Use of A Free Radical Method to Evaluate Antioxidant Activity. Lebensm-Wiss.U.- Technol., 28, 25-30.

[15] Sarı, T. \& Paksoy, M., (2004). The quality of some Carrot cultivars sown at different sowing times in Konya province, Selcuk University The journal of Agricultural Faculty, 18 (33), 17-22 (in Turkish).

[16] Özkan, M., (2009). Siyah Havuç Suyu Konsantresi Üretimi ve Depolanması Sürecinde Fenolik Maddeler ve Antosiyaninlerdeki Değişimler ve Bu Değişimlerin Antioksidan Aktivite ile İlişkisi. Ankara Üniversitesi Bilimsel Araştırma Projesi Kesin Raporu, Proje numaras1: 07B4343002.

[17] Algarra, M., Fernandes, A., Mateus, N., de Freitas, V., Da Silva, J. C. E., \& Casado, J., (2014). Anthocyanin profile and antioxidant capacity of black carrots (Daucus carota L. ssp. sativus var. atrorubens Alef.) from Cuevas Baja., Spain, Journal of Food Composition and Analysis,33(1), 71-76.

[18] Ekici, L., Ozturk, I., Karaman, S., Caliskan, O., Tornuk, F., Sagdic, O., \& Yetim, H., (2015). Effects of black carrot concentrate on some physicochemical, textural, bioactive, aroma and sensory properties of sucuk, a traditional Turkish dry-fermented sausage. LWTFood Science and Technology, 62(1), 718-726. 